\title{
Midurethral Slings Combined to Cosmetic Gynecologycal Surgeries: Our Experience of 13 Years
}

\author{
Jack Isaac Pardo Schanz* and Vicente Solá Dalenz \\ Department of Gynecology
}

Submission: March 01, 2017; Published: March 20, 2017

*Corresponding author: Jack Isaac Pardo Schanz, Department of Gynecology, Clinica MEDS, Santiago, Chile, Email: drjackpardo.s@gmail.com

\section{Short Communication}

Almost over two decades ago the urogynecology Experimentsignificant progress with the incorporation of midurethral slings (MUS) for urinary stress incontinence treatment (USI). Simultaneously, started a tendency to provide cosmetic gynecological surgical procedures, wich in spite of being available in gynecological practice Begun and to be standardized massive. Become a real sub-specialty the Cosmetogynecology $[1,2]$. These procedures are mainly, labioplasty of labia Minora and Labia Mayora [3,4]. Colpoperineoplasty for Symptomatic Vaginal Amplitude/or Vaginal Relaxation Syndrome (VRS) [5]. usually known as vaginal rejuvenation Our last 13years experience is presented.

In this short communication we present the experience of two urogynecologist and cosmetic gynecological surgeons in the association of MUS with cosmetic gynecological surgeries (CGS). The objective is to demonstrate that the high association presented makes the SUI to be highly frequently observed associated to aesthetic genital disorders as well as to feelings of VRS. With this association we want to establish that urogynecologists should be, at least, prepared to diagnose and treat or at least refer these patients in order to solve both problems in one surgical act. Secondly, this review provides important casuistry showing the distribution of the different slings used by the authors.

All the MUS carried out by the two authors from October 2003 until December 2016 Were reviewed. SUS carried out previously are not included since we did not offer CGS before that date. SUS conducted in public hospital were not included (more than 300) since due to obvious reasons these were not likely to be combined with CGS. Every MUS was listed by state of the art and device used. Everyone was checked if CGS was made concomitantly. On the other hand, we wanted to assess whether the SUS and CGS combination increases surgical complications and / or adversely affect each other.
Table 1: Distribution of Cosmetic Gynecological Surgeries.

\begin{tabular}{|c|c|}
\hline Vaginal Rejuvenation & 441 \\
\hline Labiaplasty & 234 \\
\hline Labia Mayora Lifting & 57 \\
\hline & 732 \\
\hline
\end{tabular}

Table 2: Distribution of Midurethral Slings.

\begin{tabular}{|c|c|c|c|}
\hline $\begin{array}{c}\text { Type of } \\
\text { Misurethral } \\
\text { Sling }\end{array}$ & Type of Device & $\mathbf{n}$ & $\%$ \\
\hline $\begin{array}{c}\text { Transobturator } \\
\text { Sling }\end{array}$ & TVT-O ${ }^{\mathrm{TM}}$ & 566 & 56.43 \\
\hline $\begin{array}{l}\text { Transobturator } \\
\text { Sling }\end{array}$ & Monarc $^{\mathrm{TM}}$ & 34 & 3.39 \\
\hline $\begin{array}{c}\text { Minisling ( } \\
\text { single insicion) }\end{array}$ & Miniarc $^{\mathrm{TM}}$ & 80 & 7.98 \\
\hline $\begin{array}{c}\text { Minisling ( } \\
\text { single insicion) }\end{array}$ & TVT-Secure $^{\mathrm{TM}}$ & 171 & 17.05 \\
\hline $\begin{array}{l}\text { Retropubic } \\
\text { Sling }\end{array}$ & TVT $^{\text {тM }}$ & 122 & 12.16 \\
\hline $\begin{array}{l}\text { Retropubic } \\
\text { Sling }\end{array}$ & TVT-Exact $^{\mathrm{TM}}$ & 21 & 2.09 \\
\hline $\begin{array}{l}\text { Retropubic } \\
\quad \text { Sling }\end{array}$ & Retroarc $^{\mathrm{TM}}$ & 9 & 0.90 \\
\hline & & 1003 & 100.00 \\
\hline
\end{tabular}


Journal of Gynecology and Women's Health

Table 3: Distribution of Cosmetic Surgeries according to type of MUS.

\begin{tabular}{|c|c|c|c|c|c|c|}
\hline & Vaginal Rejuvenation & & Labiaplasty & & Labia Mayora Lifting & \\
\hline Type of Device & $\mathrm{n}$ & $\%$ & $\mathrm{n}$ & $\%$ & $\mathrm{n}$ & $\%$ \\
\hline TVT-O ${ }^{\mathrm{TM}}$ & 237 & 53.74 & 135 & 57.69 & 32 & 56.14 \\
\hline Monarc $^{\mathrm{TM}}$ & 29 & 6.58 & 25 & 10.68 & 8 & 14.04 \\
\hline Miniarc $^{\mathrm{TM}}$ & 62 & 14.06 & 36 & 15.38 & 7 & 12.28 \\
\hline TVT-Secure $^{\mathrm{TM}}$ & 69 & 15.65 & 24 & 10.26 & 4 & 7.02 \\
\hline TVT $^{\text {тм }}$ & 34 & 7.71 & 9 & 3.85 & 4 & 7.02 \\
\hline TVT-Exact $^{\mathrm{T}}$ & 7 & 1.59 & 4 & 1.71 & 1 & 1.75 \\
\hline \multirow[t]{2}{*}{ Retroarc $^{\mathrm{TM}}$} & 3 & 0.68 & 1 & 0.43 & 1 & 1.75 \\
\hline & 441 & 100.00 & 234 & 100.00 & 57 & 100.00 \\
\hline
\end{tabular}

During the period under study1003 MUS were carried out. There was a total of 732 CGS in these patients (Table 1), where percentage factor from total is not applied because some patients had three CGS and others just one. MUS were distributed in 566 TVT-0, 34 Monarc, 80 Miniarc, 171 TVT Secure , 122 TVT , 21 TVT-Exact and 9Retroarc. In the same period, 234 labia minora labiaplasty (23.3\%), 57 Lifting of labia majora (5.7\%) and 441 colpoperineoplasty by vaginal relaxation condition (44.0\%) were made to these 1003 patients (Table 2). Grouping the SUS in Transobturators (TVT-O and Monarc), 63,3\%, Minisling (Miniarc and TVT-Secure), 25,9\% and retropubic (TVT, TVT exact and Retroarc), 15,2\%, show a not significantly different distribution between transobturators and minisling concerning the CGS ( Table 3). But it is clear that patients who underwent retropubic SUS had less CGS, which could be since they are older women with more severe IOE or more complicated cases, where the main problem does not often supports combination with CGS. Regarding patients who underwent MUS without CGS associated, these are not over the 30\% (28.2\%) of all cases. On the other hand, many patients with or without CGS had other(s) surgeries, such as, colpoperineoplasty for genital prolapse with or without meshes, hysterectomies, adnexectomies, laparoscopic tubal sterilizations. MUS as isolated surgery are not more than $15 \%$ of our cases. We did not find any associated complications or serious conditions due to combined one CGS. Of course our important combination of MUS and CGS could be influenced because in private practice patients looking for SUI and Cosmetic procedures find in our team the overall resolution for their complaints.

\section{Conclusion}

In our experience, SUS association with CGS is not only very common but also safe. On the other hand, we believe that associate a CGS, improves experience of patient, improves quality life and saves time and money for something the patient thought anyway solve.

\section{Images}

42 years old patient para 3 vaginal deliveries. Labia Minora Hipertrophia, Vaginal Laxitude and Urinary Stress Incontinence.
Surgeries: Laser Vaginal Rejuvenation ( Colpoperineoplasty), Laser labiaplasty and TVT-O (Figure 1-3).

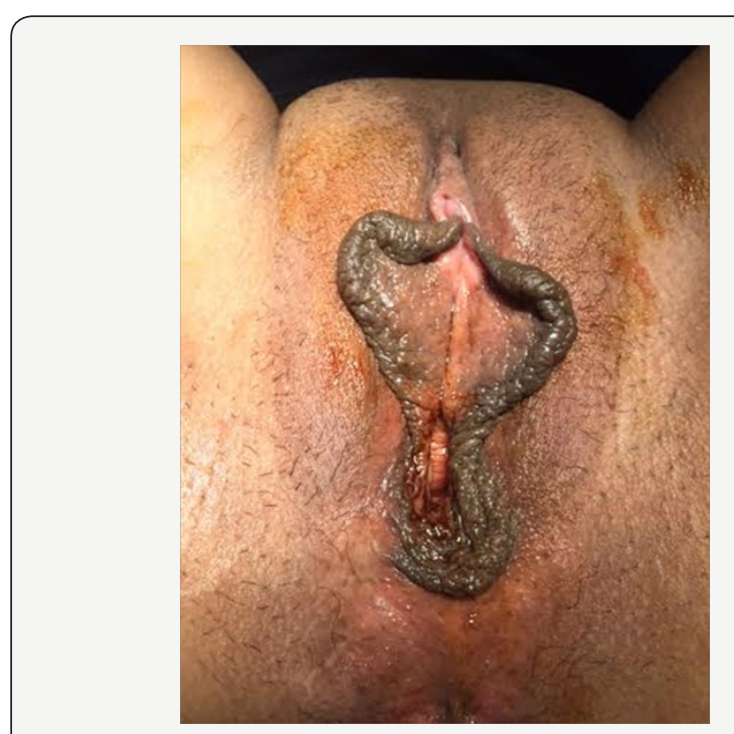

Figure 1: Before

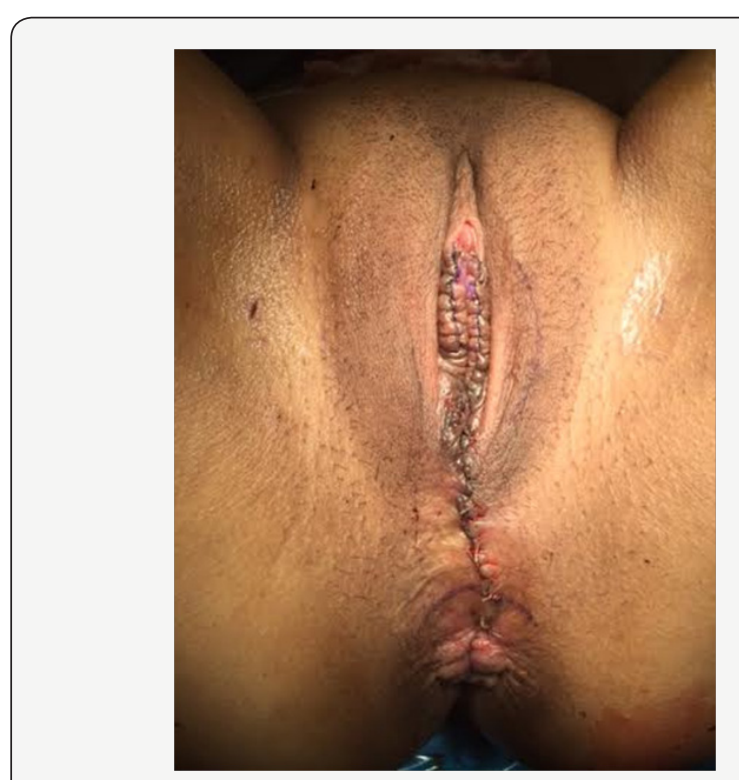

Figure 2: After Surgery. 


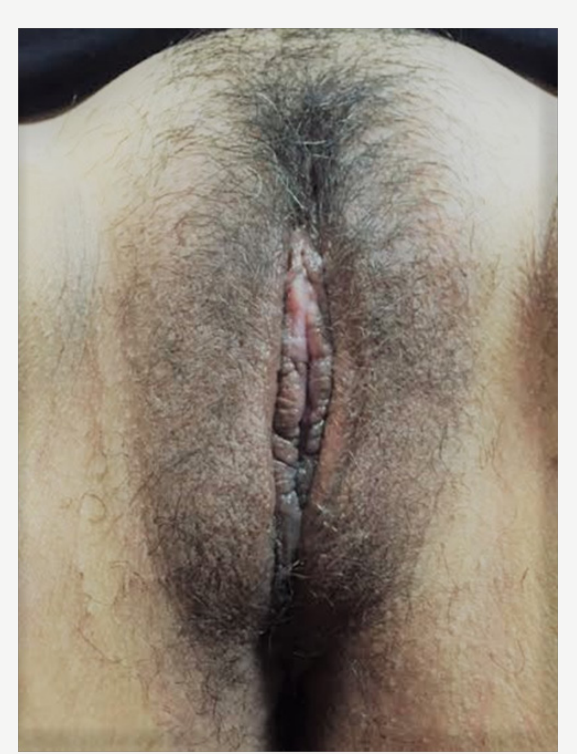

Figure 3: Final result (4 month later).

\section{References}

1. Solà V, Ricci P, Pardo J (2009) Comment on Palma and Rosenbaum: "The ethical challenge of surgical innovation International Urogynecology Journal 20(10): 1281.

2. (2007) Int Urogynecol J Pelvic Floor Dysfunct. 18(Suppl 1): S 222.

3. Pardo J, Sola V, Ricci P (2012) Labia Majora Lifting: Aesthetic and Functional Solution for Hypertrophy and/or Flaccidity of Labia Majora. American Journal of Cosmetic Surgery 29(2): 128-132.

4. Pardo JS (2006) Colpoperineoplasty in women with a sensation of a wide vagina. Acta Obstet Gynecol Scand 85(9): 1125-1127.

5. (2006) Laser labioplasty of labia minora. Int J Gynaecol Obstet 93(1): 38-43.

\section{Your next submission with Juniper Publishers} will reach you the below assets

- Quality Editorial service

- Swift Peer Review

- Reprints availability

- E-prints Service

- Manuscript Podcast for convenient understanding

- Global attainment for your research

- Manuscript accessibility in different formats

( Pdf, E-pub, Full Text, Audio)

- Unceasing customer service

Track the below URL for one-step submission https://juniperpublishers.com/online-submission.php 